The University of Maine

DigitalCommons@UMaine

$11-16-2021$

\title{
Timber harvesting on fragile ground and impacts of uncertainties in the operational costs
}

\author{
Alex K. George \\ University of Maine, alex.george@maine.edu \\ Anil Raj Kizha \\ University of Maine, anil.kizha@maine.edu \\ Laura Kenefic \\ Northern Research Station, U.S. Forest Service
}

Follow this and additional works at: https://digitalcommons.library.umaine.edu/sfr_facpub

Part of the Forest Biology Commons

\section{Repository Citation}

George, Alex K.; Kizha, Anil Raj; and Kenefic, Laura, "Timber harvesting on fragile ground and impacts of uncertainties in the operational costs" (2021). Forest Resources Faculty Scholarship. 9.

https://digitalcommons.library.umaine.edu/sfr_facpub/9

This Article is brought to you for free and open access by DigitalCommons@UMaine. It has been accepted for inclusion in Forest Resources Faculty Scholarship by an authorized administrator of DigitalCommons@UMaine. For more information, please contact um.library.technical.services@maine.edu. 


\title{
Timber harvesting on fragile ground and impacts of uncertainties in the operational costs
}

\author{
Alex K. George ${ }^{a}$, Anil Raj Kizha $\mathbb{D D}^{\mathrm{a}}$, and Laura Kenefic ${ }^{\mathrm{b}}$

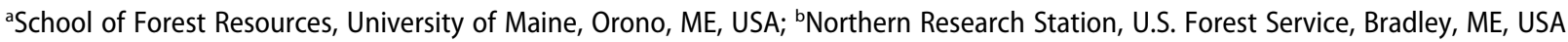

\begin{abstract}
Forested wetlands with high water tables are sensitive to disruption from harvesting yet support commercially desired tree species like northern white-cedar. Winter harvest was conducted in Maine, USA, to compare operational costs and productivity of cut-to-length harvesting in cedar (fragile soil) and non-cedar stands (mixedwood, sturdy soil), evaluate uncertainties in harvesting costs and influential factors, and forecast time for post-harvest recovery to pre-harvest volumes. Operational costs were calculated using detailed time and motion studies. Operational costs for the cedar stands were higher than non-cedar. Regression models were developed for harvesters, forwarders, and self-loading trucks; number of logs per cycle was a common factor. Sensitivity analysis showed the dependence of operational costs on labor and fuel costs. Forest Vegetation Simulator projections were used to assess harvest sustainability and suggested the time required to regrow harvested merchantable volume is comparable to cutting cycles recommended for similar treatments in the region. Predicted growth rates exceed those reported regionally on similar sites, suggesting additional study of post-harvest response is warranted. Results highlight site constraints on both operational and stand productivity in lowlands and will be useful for timber harvesting decision-making and forest management planning if combined with assessment of residual stand growth response.
\end{abstract}

\section{ARTICLE HISTORY}

Received 27 May 2021

Accepted 29 September 2021

\section{KEYWORDS}

Cut-to-length; forest vegetation simulator (FVS); logging; northern whitecedar; sensitivity analysis; sustainable forest management

\section{Introduction}

Forested wetlands, characterized by woody vegetation six meters or taller, provide a wide variety of ecosystem services to humankind (Jiang 2016). In the state of Maine, USA, forested wetlands account for $56 \%$ of total wetlands (Tiner 2007). The major forested wetlands of Maine are cedar swamps, spruce bogs, red maple fens, and silver maple floodplain forests (PIN, 2020). Northern white-cedar (Thuja occidentalis $\mathrm{L}$.) is one of the most important tree species in forested wetlands of northeastern USA and southeastern Canada in terms of conservation and timber values (Boulfroy et al. 2012; Wesely et al. 2018).

Approximately $75 \%$ of cedar forests are found in habitats broadly described as lowlands in the northeastern USA (Boulfroy et al. 2012). Of these, $54 \%$ and $21 \%$ are located in flatwoods (relatively flat areas outside of floodplains; Ainslie 2002) and swamps (forested wetlands), respectively (Boulfroy et al. 2012). Cedar occurs in both mixed and pure stands where sites are characterized by deep, organic, and poorly drained soil conditions (Boulfroy et al. 2012; Frohn 2017). These stands are relatively under-managed because of the fragile ecosystem where the species grows (Kenefic 2013). In terms of timber harvesting, accessibility to the stand, absence of sturdy soil, and a high water table can pose hazards to both timber harvesting equipment and the ecosystem (Boulfroy et al. 2012).

Reduced volume of cedar growing stock in recent years in some parts of its range is attributed to a wide variety of stand conditions that create challenges for sustainable management
(Boulfroy et al. 2012; Huff and McWilliams 2016). Yet active management is necessary to ensure the economic (specialty products, shingles, essential oils), social (traditional uses by Native Americans), and ecosystem (biodiversity maintenance and wildlife habitat) benefits provided by cedar stands (Verme and Johnston 1986; Botti 1991; Heitzman et al. 1997; Boulfroy et al. 2012). Understanding the cost and productivity of harvesting lowland cedar is critical to sustainable management of these stands and the ecosystem services they provide.

Timber harvesting involving heavy machines, such as harvesters, can cause soil disturbances in the form of compaction and rutting (Soman et al. 2019, 2020; Addison et al. 2019). Furthermore, lowland sites such as forested wetlands that are water-logged for a portion of the year tend to have smaller trees compared to uplands (Hofmeyer et al. 2009). This can lead to reduced productivity in such stands, because the cost of timber harvesting per unit volume is a function of the average tree size harvested (Kizha and Han 2016; Soman et al. 2019). Additionally, shorter timber harvesting seasons, an impact of climate change, may have contributed to the observed $47 \%$ decline in cedar harvest in Maine since 2000 (Berry et al. 2019; Woodall et al. 2019). Changing winter temperatures can result in fewer days with frozen ground and snow cover, both of which are necessary for harvesting operations in lowlands. In Maine, winter warming has resulted in a lower number (decreased from 26 to 16 days) of nights less than $-17^{\circ} \mathrm{C}$ over the last two decades (1995-2014) (Runkel et al. 2017). This has resulted in the shifting of timber harvesting operations from some lowlands to more upland sites (Keenan 2015). 
Silvics of cedar suggest the use of selection or irregular shelterwood systems for retention and release of wellestablished cedar trees and to begin regeneration (Boulfroy et al. 2012; Kenefic 2013). Moreover, partial harvest prescriptions have fewer detrimental effects on fragile sites than clearcutting (Jiang 2016), and thus are preferable on lowlands. This is relevant in the northeastern USA and in Maine specifically, due to the prevalence of harvests such as overstory removals (removing all trees to release established regeneration) and commercial clearcuts (removing all merchantable trees) (Belair and Ducey 2018; Maine Forest Service 2021). Further, to sustainably manage lowland cedar, operations need to be limited to frozen ground conditions to reduce the impacts of soil compaction, rutting, root damage, risk of windthrow, and the probability of machines sinking (Boulfroy et al. 2012; Rossman et al. 2016; Russell et al. 2018; George et al. 2019).

Within mechanized ground-based harvesting systems available in the study region, the cut-to-length (CTL) harvesting method, where the entire tree is processed at the stump, is ideal for fragile sites as compared to conventional whole-tree harvesting methods (Han et al. 2009; Jiang 2016; Kizha et al. 2021). Harvest residue (slash) from CTL harvesting is left on site to armor the trails and provide support, reducing the potential for soil disturbance, and enhancing safety and efficiency of the operation (Cudzik et al. 2017). Additionally, logs are carried (forwarded) during primary transportation thereby reducing soil disturbance and damage to advanced regeneration relative to whole-tree skidding; for this reason, this method is compatible with cedar management on sites with established regeneration (Waters et al. 2004). CTL equipment is also relatively compact, resulting in narrower trails; the equipment has tracks that disperse weight; and the number of machine passes are fewer as compared to the whole tree-method (Rossman et al. 2016; Louis and Kizha 2021). The above-mentioned factors make the CTL harvesting method the preferred option for lowland cedar harvesting.

Predicting the volume of timber available at the next entry is crucial information to determine sustainable harvest levels over the management period. The Forest Vegetation Simulator (FVS) and its regional variants are commonly used growth and yield models in the USA, where growth rates can be predicted based on stand information and inventory data (Canavan and Ramm 2000). FVS is an individual-tree model that supports the specification of management prescriptions by providing information on maximum allowable height and diameter, Stand Density Index (SDI), species, and silviculture (i.e., trees of specified sizes and species are removed prior to projection to simulate silvicultural treatment) (Crookston and Dixon 2005; Dixon and Keyser 2008).

Estimating the cost of harvesting and assessing the amount of available timber in the future will help determine the feasibility of harvesting lowland cedar growing in fragile ecosystems. The specific objectives of this study were to: a) compare the cost and productivity of cut-to-length operations between lowland cedar on fragile soil and a non-cedar mixedwood stand on sturdy soil; b) evaluate uncertainties in the harvesting costs with respect to influential factors using sensitivity analysis; and c) forecast time to recover to pre-harvest volume using FVS, for the purpose of scheduling subsequent harvest operations.

\section{Materials and methods}

\section{Study area}

The study was conducted in the Penobscot Experimental Forest (PEF) in Eddington $\left(44^{\circ} 49^{\prime} 56^{\prime \prime} \mathrm{N}, 68^{\circ} 36^{\prime} 26^{\prime \prime} \mathrm{W}\right.$; Site 1) and Danforth $\left(45^{\circ} 37^{\prime} 56^{\prime \prime} \mathrm{N}, 67^{\circ} 48^{\prime} 14^{\prime \prime} \mathrm{W}\right.$; Site 2), Maine, USA (Figure 1). In site 1 (S1), two treatments with different ground conditions were studied: S1 Treatment 1 (S1T1), a 4.4-ha cedar-dominated stand in a lowland characterized by wet, marshy land with organic soil and high water table throughout the growing season, and Treatment 2 (S1T2), a 12.5-ha mixedwood stand on sturdy soil. In S1T1, average depth to the water table was 0.20 and $0.34 \mathrm{~m}$ for spring and summer respectively. For S1T2, average depth to the water table was $1.08 \mathrm{~m}$ in spring and $3.20 \mathrm{~m}$ in summer (Murphy et al. 2011; UNB Forest Watershed Research Center 2014). The average temperature and snow depth during the operations was $7.4^{\circ} \mathrm{C}$ and $16 \mathrm{~cm}$, respectively. Soil types present in S1T1 were Bucksport and Wonsqueak muck (83\%) and Peru-Colonel-Turnbridge association (17\%); the slope was $0-3 \%$. In S1T2, soil types BecketSkerry complex (46\%), Peru-Colonel-Tunbridge association (29\%), and Monarda-Telos complex (21\%) dominated, and the slope ranged from 2\% to 15\% (Soil Survey Staff 2019).

In site 2 (S2) treatment 1 (S2T1), a 3.3-ha cedar-dominated stand similar to S1T1 was studied. The site was dominated by Monarda-Burnham complex soil type and the slope ranged from 0 to $3 \%$. The average temperature was $-9.8^{\circ} \mathrm{C}$ during the operatons. Snow depth and water table information was not available.

\section{Stand inventory}

S1T1 was inventoried using nested circular plots (Kenefic et al. 2018). Nine fixed-radius plots of $0.08 \mathrm{ha}$ ( $16.1 \mathrm{~m}$ radius) were used to measure the diameter at breast height ( $\mathrm{dbh}$, at $1.37 \mathrm{~m}$ ), tree height, and species of trees $\geq 11.4 \mathrm{~cm} \mathrm{dbh}$. Stand density of S1T1 was 1320 trees ha ${ }^{-1}$ with a basal area of $51 \mathrm{~m}^{2} \mathrm{ha}^{-1}$ and quadratic mean diameter (QMD) of the stand was $22.1 \mathrm{~cm}$. Cedar (81\%) was the dominant species (Table 1). Other species included red maple (Acer rubrum L.; 8\%), American larch (Larix laricina (Du Roi) K. Koch.; 7\%), and red spruce (Picea rubens Sarg.; 1\%) (Table 1).

S1T2 had 24 variable-radius plots inventoried utilizing a 20 Basal Area Factor prism. The parameters recorded were similar to those of the fixed-area plots described above. The dominant species was eastern hemlock (Tsuga canadensis (L.) Carr.; 54\%). Other species were eastern white pine (Pinus strobus L.; $23 \%)$, cedar (8\%), red maple (6\%), black ash (Fraxinus nigra Marsh.; 3\%), yellow birch (Betula alleghaniensis Britt.; 1\%), quaking aspen (Populus tremuloides Michx.; 1\%), and paper birch (Betula papyrifera Marsh.; 1\%). The treatment had a basal area of $40 \mathrm{~m}^{2} \mathrm{ha}^{-1}$ with 739 trees ha ${ }^{-1}$ (Table 1) and the QMD was $26.2 \mathrm{~cm}$.

S2T1 was inventoried (4 plots) with the method used in S1T1. Stand density was 1085 trees ha ${ }^{-1}$ with a basal area of 46 $\mathrm{m}^{2} \mathrm{ha}^{-1}$ and the QMD was $23.4 \mathrm{~cm}$. Cedar (81\%) was the dominant species; other species were red maple $(8 \%)$, red 

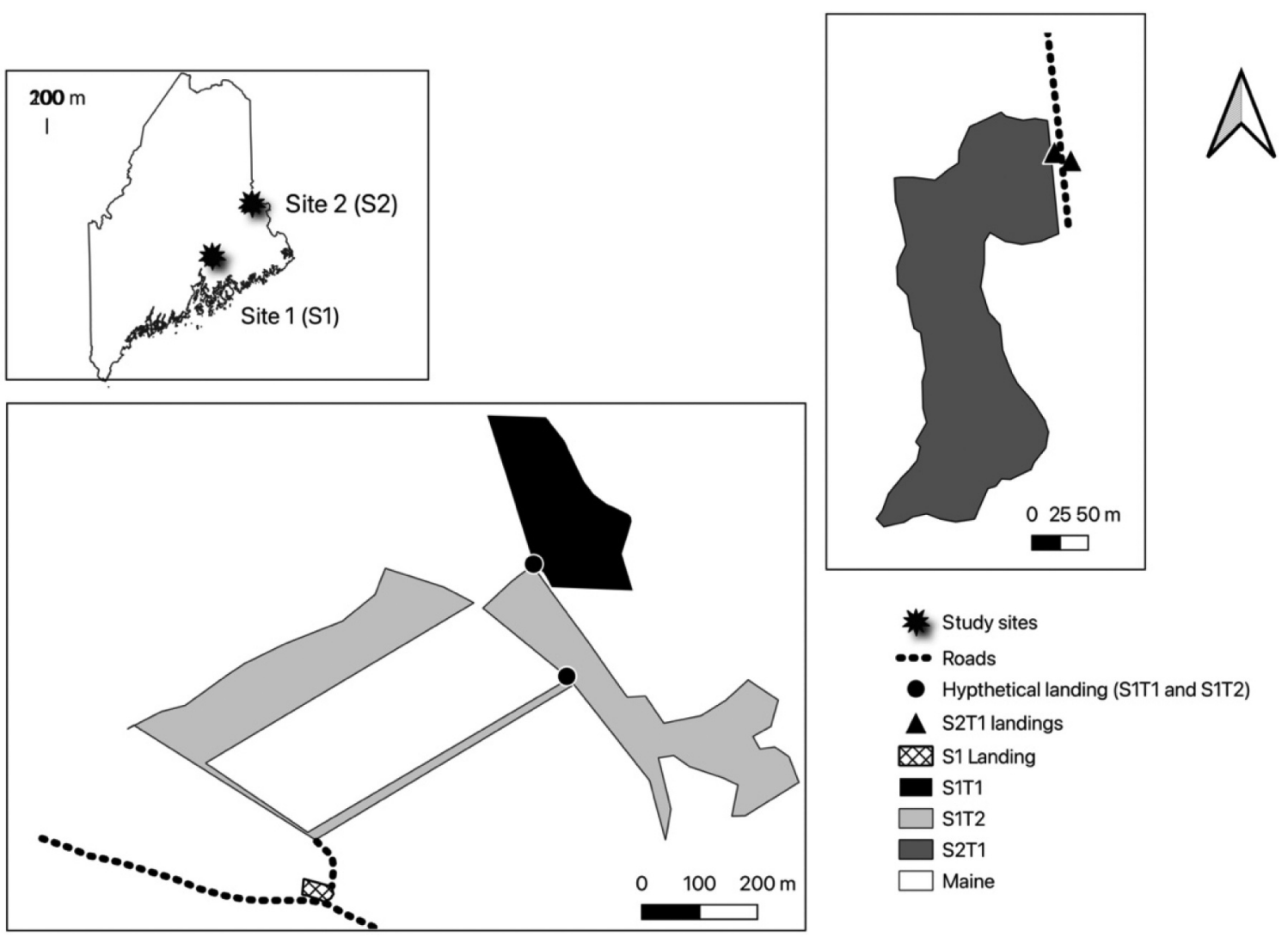

Figure 1. S1T1 (lowland cedar), S1T2 (non-cedar stand) and S2T1(lowland cedar) in the study site along with the actual landing and hypothetical landing.

Table 1. Stand inventory descriptions for S1T1, S1T2, and S2T1. S1T1 and S2T1 were cedar dominated stands on fragile ground, whereas S1T2 was a non-cedar stand on a more sturdy soil profile.

\begin{tabular}{lccc}
\hline Stand Attributes & S1T1 & S1T2 & S2T1 \\
\hline Area (ha) & 4.4 & 12.5 & 3.3 \\
Basal Area $\left(\mathrm{m}^{2} \mathrm{ha}^{-1}\right)$ & $51 \pm 2$ & $40 \pm 3$ & $46 \pm 5$ \\
Trees per ha & $1320 \pm 31$ & $739 \pm 59$ & $1085 \pm 174$ \\
$\mathrm{QMD}^{\mathrm{a}}(\mathrm{cm})$ & 22.1 & 26.2 & 23.4 \\
Volume $\left(\mathrm{m}^{3} \mathrm{ha}^{-1}\right)$ & 315 & 305 & 296 \\
Timber harvested $\left(\mathrm{m}^{3} \mathrm{ha}^{-1}\right)$ & 120 & 127 & 108 \\
Removal percentage (as percentage of & 38.1 & 41.6 & 36.5 \\
$\quad$ volume) & & & \\
\hline
\end{tabular}

${ }^{\mathrm{a} Q M D-}$ Quadratic Mean Diameter

spruce (7\%), balsam fir (Abies balsamea (L.) Mill; 2\%), and paper birch (1\%) (Table 1). The stand inventory was performed by US Forest Service and the University of Maine Forests Office, which resulted in the difference in inventory techniques adopted.

\section{Silvicultural prescription}

Variants of the irregular shelterwood system were prescribed in all the treatments to improve growth of desired residual trees and establish regeneration. Silvicultural prescriptions for the treatments are detailed in George et al. (2019). After the harvest, basal area (BA) of S1T1, S1T2, and S2T1 was reduced to 31,22 , and $29 \mathrm{~m}^{2} \mathrm{ha}^{-1}$, respectively.

\section{Harvesting operation}

A cut-to-length (CTL) harvesting method was employed for both treatments. The operation was conducted during the winter, February 2019 in S1 and February 2020 in S2, during which the ground was frozen, ensuring stability for the machines to maneuver over the fragile soil conditions. The operation lasted four days each in S1T1 and S2T1, and eight days in S1T2. Machines and operators were different for S1 and S2. The operators had more than six years of experience.

\section{Operational phases}

Operational phases were felling and processing (harvester), extraction (forwarder), and loading (self-loading trucks). The components of Delay Free Cycle time (DFC; Table 2) used for detailed time-motion study are detailed in George et al. (2019). Information on the machines used is provided in Table 3.

S1 had a higher average forwarding distance than S2. For a realistic comparison of forwarding cost irrespective of the distance due to stand conditions, a hypothetical (imaginary) landing was presumed adjacent to the stand boundaries of S1T1 and S1T2. Difference in distances between the actual and hypothetical landings were 911 and $837 \mathrm{~m}$ for S1T1 
Table 2. Cycle elements and independent variables recorded during the detailed time and motion study (George et al. 2019).

\begin{tabular}{ccc}
\hline Operational phases & Cycle elements & Recorded predictor variable(s) \\
\hline $\begin{array}{c}\text { Felling and processing } \\
\text { (Harvester) }\end{array}$ & $\begin{array}{c}\text { Travel to trees } \\
\text { Cutting }\end{array}$ & $\begin{array}{c}\text { Butt-end diameters }(\mathrm{cm}) \\
\text { Decking distance }(\mathrm{m})\end{array}$ \\
& Processing & Distance between trees $(\mathrm{m})$ \\
& Decking & Number of cuts per cycle \\
& & Number of logs per cycle \\
& & Species \\
Extraction & Travel empty & Butt-end diameters $(\mathrm{cm})$ \\
(Forwarder) & Travel loaded & Loaded distance $(\mathrm{m})$ \\
& Loading & Number of pieces \\
& Unloading & Species \\
& & Travel empty distance $(\mathrm{m})$ \\
Loading & Swing empty & Butt-end diameters $(\mathrm{cm})$ \\
(Self-loading truck) & Grappling & Length of log $(\mathrm{m})$ \\
& Swing loaded & Number of pieces \\
& Sorting & Species \\
\hline
\end{tabular}

and S1T2, respectively. The actual landing was at the stand boundary in S2T1. This has helped in an effective comparison of extraction cost between the sites. Time and distance to reach the hypothetical and actual landings were separately measured for each forwarding cycle. For each DFC, travel time from hypothetical to actual landing was deducted and variation in cost of extraction due to difference in forwarding distance was evaluated for S1T1 and S1T2.

\section{Harvesting cost calculations}

Harvesting cost was determined for the stump-to-truck phase of the operation. By assimilating machine rate (productivity and operating cost of the machine, US\$ $\left.\mathrm{PMH}^{-1}\right)$, average DFC time, and volume produced (log scaling, Huber's formula) per DFC, the cost of operation was evaluated per unit volume (US\$ $\mathrm{m}^{-3}$ ) of wood generated from the treatments (Miyata 1980; George et al. 2019; Soman et al. 2019). The cost of felling and processing per unit area
(US\$ ha ${ }^{-1}$ ) was estimated by multiplying wood harvested per unit area $\left(\mathrm{m}^{3} \mathrm{ha}^{-1}\right)$ and operating cost per unit volume (US\$ $\mathrm{m}^{-3}$ ).

\section{Cost allocation}

To evaluate the individual cost of felling and processing for the different assortments, an exclusive product allocation was carried out, in which DFC times from the whole operation were separated to calculate the cost and productivity for the three assortments (cedar, other softwoods, and hardwoods) (Louis and Kizha 2019).

\section{Sensitivity analysis}

A local sensitivity analysis was conducted to understand the effect of fluctuation in fuel prices and labor wages on the cost of operations, keeping all other elements constant (Kizha and Han 2016). For comparison, the minimum wage was kept as US\$ 12.00 per scheduled machine hour (SMH), as per legal regulation for the state of Maine at the time of this study. The maximum wage used was US\$ 30.00 per SMH. Fuel price altered between US\$ 0.50 and 1.5 per liter.

\section{Stand projection}

Treatments were projected using the FVS Northeast Variant's Acadian growth and yield model for merchantable volume of timber, which has been developed for the Acadian region, where the study sites were located. Treatments were projected until the stands reached preharvest merchantable volume. Based on tree age and height data collected on site, site indices of $12 \mathrm{~m}$ for cedar and 21 $\mathrm{m}$ for white pine at an index age of 50 years were used for the projections.

Table 3. Machine rate and cost of the equipment used in the harvesting. All the information was provided by the forest management company which owned and operated the equipment.

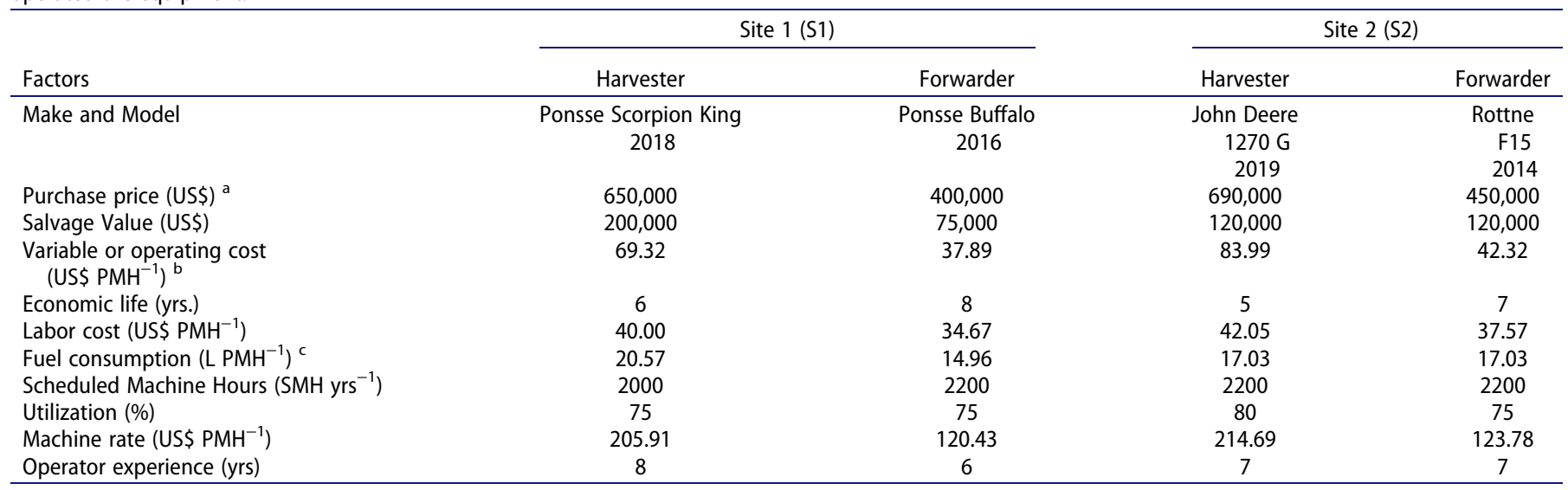

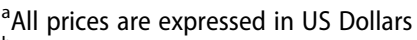

${ }^{\text {bPMH }}=$ Productive Machine Hour

${ }^{\mathrm{C}} \mathrm{LPMH}^{-1}=$ Liters per Productive Machine Hour 


\section{Statistical analysis}

R software (version 4.0.3) was used to perform statistical analysis. Datasets were checked for the assumptions of linear regression. Linear regression was performed keeping DFC time as the dependent variable (Table 2). Models were selected based on the lowest AIC values using the MASS package (Venables and Ripley 2002). ANOVA followed by Tukey HSD post hoc were conducted to determine significant difference $(p<0.05)$ between the observed variables. Standard errors were estimated and denoted after parameter values.

\section{Results}

\section{Harvesting operation}

A total of 528,1588 , and $356 \mathrm{~m}^{3}$ of wood was harvested from S1T1, S1T2, and S2T1, respectively (Table 1). In S1T1, the majority of logs were cedar $(72 \%)$ followed by hardwood (13\%), larch (10\%), and spruce (2\%). In S1T2, hardwoods $(48 \%)$ constituted the most followed by hemlock $(26 \%)$, cedar (14\%), pine (6\%), fir (4\%) and spruce (2\%). In S2T1, a similar trend to S1T1 was observed, i.e., cedar $(52 \%)$, hardwood $(31 \%)$, and spruce $(17 \%)$. ANOVA revealed a significant difference in $\mathrm{dbh}(p<0.01)$ between S1T1 $(21.27 \pm 0.20 \mathrm{~cm})$ and S1T2 $(35.36 \pm 2.43 \mathrm{~cm})$, and $\mathrm{S} 1 \mathrm{~T} 2$ and S2T1 $(22.15 \pm 0.38 \mathrm{~cm})$. However, no difference was found between S1T1 and S2T1.

Total cost of operating in S1T1 (US\$ $16.64 \mathrm{~m}^{-3}$ ) was higher compared to S1T2 (US\$ $9.56 \mathrm{~m}^{-3}$ ) and S2T1 (US\$ $13.17 \mathrm{~m}^{-3}$ ) (Table 4). Cost of harvesting cedar-dominated stands was higher than a non-cedar stand. Equipment and operators were the same for S1T1 and S1T2, difference in cost can be attributed to stand conditions, number of logs handled, average log size and extraction distance (Table 5) (Kizha and Han 2016; Baek 2018; Proto et al. 2018; Soman et al. 2019).

\section{Felling and processing}

From all the treatments a total of 542 DFCs were recorded. ANOVA followed by Tukey HSD post-hoc test showed a significant difference in average DFC time between S1T1 $(31.7 \pm 1.63 \mathrm{sec})$ and S1T2 $(39.42 \pm 2.93 \mathrm{sec})(p=0.03)$, and between S1T2 and S2T1 $(24.91 \pm 1.14 \mathrm{sec})(p<0.01)$. No significant difference was observed between S1T1 and S2T1 $(p=0.19)$. The processing time contributed most to the DFC time $(48 \% ; 15.51 \pm 1.30 \mathrm{sec})$ in S1T1, 61\% $(24.07 \pm 2.41 \mathrm{sec})$ in $\mathrm{S} 1 \mathrm{~T} 2$, and $69 \%(17.24 \pm 0.64 \mathrm{sec})$ in S2T1, followed by travel time between trees, decking time, and felling time. Processing time differed significantly between S1T1 and S1T2 only $(p<0.01)$ and the harvester produced a significantly lower number of logs per cycle in
Table 4. Cost (US\$ $\mathrm{m}^{-3}$ ) and productivity $\left(\mathrm{m}^{3} \mathrm{PMH}^{-1}\right.$, Productive Machine Hour) of each operational phase.

\begin{tabular}{lccccccc}
\hline & \multicolumn{3}{c}{ Cost } & & & \multicolumn{3}{c}{ Productivity } \\
\cline { 2 - 4 } \cline { 5 - 6 } Operational phase & S1T1 & S1T2 & S2T1 & & S1T1 & S1T2 & S2T1 \\
\hline Felling and Processing (Harvester) & 6.45 & 3.80 & 5.78 & & 31.95 & 54.18 & 37.14 \\
Extraction (Forwarder) $_{\text {Loading }^{\mathrm{a}} \text { (Self-loading truck) }}$ & $8.85^{\mathrm{b}}$ & $4.42^{\mathrm{b}}$ & 6.05 & & 13.64 & 27.26 & 20.46 \\
Total & 1.34 & 1.34 & 1.37 & & 64.48 & 64.48 & 63.13 \\
\cline { 5 - 6 } & 16.64 & 9.56 & 13.17 & NA & NA & NA \\
\hline
\end{tabular}

${ }^{a}$ All Products were merged at the landing

${ }^{\text {bHypothetical landing }}$

S1T1 $\left(1.88 \pm 0.05 ; 0.36 \mathrm{~m}^{3} \mathrm{DFC}^{-1}\right)$ and S2T1 $(1.46 \pm 0.05$; $\left.0.32 \mathrm{~m}^{3} \mathrm{DFC}^{-1}\right)$ than S1T2 $\left(2.26 \pm 0.11 ; 0.79 \mathrm{~m}^{3} \mathrm{DFC}^{-1} ; p\right.$ $<0.01)$. Similarly, for the number of cuts per cycle, a significant difference was observed only between S1T1 $(2.14 \pm 0.07)$ and S1T2 $(2.56 \pm 0.13 ; p<0.01)$.

Cost of the felling and processing and machine productivity rates for the treatments are reported in Table 4. The costs for felling and processing were US\$ 774.00, 482.60, and $624.24 \mathrm{ha}^{-1}$ for S1T1, S1T2, and S2T1, respectively, i.e., lower cost for non-cedar stand.

\section{Extraction}

Extraction accounted for $48 \%$ of the total in-woods (stump to landing) operational costs (Table 4). Hypothetical landings were assigned in S1 to understand the variation in the cost of forwarding due to changes in forwarding distances. The extraction cost was increased to US\$ 13.33 and 7.46 $\mathrm{m}^{-3}$ (34\% and $\left.41 \%\right)$ for S1T1 and S1T2, respectively, when the logs were brought to the actual landing. This was due to the increase in forwarding distance by $911 \mathrm{~m}$ (S1T1) and $837 \mathrm{~m}$ (S1T2) which in turn increased the DFC time by 25 minutes (S1T1) and 22 minutes (S1T2), respectively. Standardizing the increased cost showed that an increase in forwarding distance by $100 \mathrm{~m}$ can increase the forwarding cost by an average of US $\$ 0.43 \mathrm{~m}^{-3}$ (US $\$ 0.49 \mathrm{~m}^{-3}$ for S1T1 and US $\$ 0.36 \mathrm{~m}^{-3}$ for S1T2). This can be affected by the terrain, slope, and other site conditions.

Loading logs (within the unit) from S1T1 ( $35 \pm 3$ minutes) took more time than S1T2 (19 \pm 3 minutes) because of the higher number of logs handled per DFC $(74.6 \pm 3.84$ for S1T1 and $55.38 \pm 6.48$ for S1T2) and difference in distances between the loading points. Relative to S1T2, S2T1 took more time (22.43 \pm 2 minutes) to load logs, and more logs were loaded $(83.43 \pm 3.60)$. At the landing, unloading time was higher for S1T1 $(11.60 \pm 1.96$ minutes $)$ compared to S1T2 (9.75 \pm 0.67 minutes) because of a larger percentage of smaller trees in the former, which resulted in the operator grappling more logs per unloading cycle element $(6.28 \pm 0.55$ for S1T1 and $3.95 \pm 0.51$ for S1T2). In S2T1, unloading time was $10.00 \pm 0.81$ minutes and unloaded

Table 5. Factors influencing the total operational costs for the treatments.

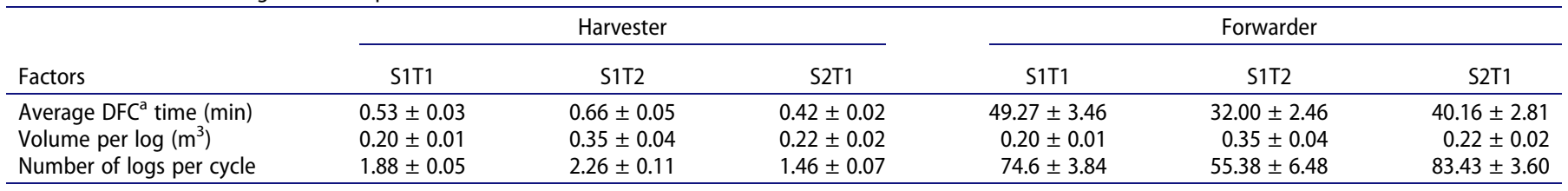

${ }^{a}$ DFC - Delay free cycle 
Table 6. Operational cost (US\$ $\left.\mathrm{m}^{-3}\right)$ and productivity $\left(\mathrm{m}^{3} \mathrm{PMH}^{-1}\right)$ of loading various products (George et al. 2019).

\begin{tabular}{lcccc}
\hline Product & $\begin{array}{c}\text { Delay free cycle time } \\
(\mathrm{sec})\end{array}$ & $\begin{array}{c}\text { Average volume per } \\
\log \left(\mathrm{m}^{3}\right)\end{array}$ & Cost & Productivity \\
\hline Cedar pulp & $25.88 \pm 1.34$ & 0.13 & 1.93 & 44.96 \\
$\begin{array}{l}\text { Hardwood } \\
\text { pulp }\end{array}$ & $44.83 \pm 2.68$ & 0.18 & 1.39 & 62.40 \\
Pine sawlog & $28.88 \pm 2.21$ & 0.48 & 1.13 & 76.28 \\
\hline
\end{tabular}

$7.29 \pm 0.59$ logs per cycle; this is similar to S1T1. There was no significant difference $(p=0.61)$ in unloading time between treatments.

\section{Loading}

It took an average of 49 minutes to load a truck. The average DFC time was estimated at $33.31 \pm 5.81$ and $34.64 \pm 2.94 \mathrm{sec}$ for S1 and S2, respectively. The loading cost for cedar pulpwood (US\$ $1.93 \mathrm{~m}^{-3}$ ) was higher compared to hardwood pulpwood (US\$ $1.39 \mathrm{~m}^{-3}$ ) (Table 6).

\section{Sensitivity analysis on the cost of operation}

The analysis showed a 50\% increase in fuel price would increase the cost of felling and processing by $5 \%$ and the extraction cost by $6 \%$. On the other hand, a $50 \%$ increase in the wage of machine operators would increase the felling and processing cost by $7 \%$ and the extraction cost by $9 \%$.

\section{Stand projection}

S1T1 had a post-harvest volume of $195 \mathrm{~m}^{3} \mathrm{ha}^{-1}$ and was projected to grow back to the pre-harvest level $\left(315 \mathrm{~m}^{3}\right.$ $\mathrm{ha}^{-1}$ ) in 20 years. S1T2 had a post-harvest volume of 178 $\mathrm{m}^{3} \mathrm{ha}^{-1}$ and was projected to take 22 years to recover to the pre-harvest level $\left(305 \mathrm{~m}^{3} \mathrm{ha}^{-1}\right)$. S2T1 was projected to take 21 years to grow back from post-harvest level (188.01 $\left.\mathrm{m}^{3} \mathrm{ha}^{-1}\right)$ to the pre-harvest level $\left(295 \mathrm{~m}^{3} \mathrm{ha}^{-1}\right)$. This reflects not only differences in harvest volume but predicted net growth. S1T1, S1T2, and S2T1 were projected to grow at a rate of $6.01,5.91$, and $5.07 \mathrm{~m}^{3} \mathrm{ha}^{-1} \mathrm{yr}^{-1}$. In addition, though the cedar and non-cedar stands are predicted to reach their previous pre-harvest merchantable volumes in about 20-22 years, projected stand densities decrease over time from 778 to 709,314 to 287 , and 682 to 618 trees ha ${ }^{-1}$ in S1T1, S1T2, and S2T1, respectively. This indicates a predicted mortality rate of 4,2 , and 3 trees $\mathrm{ha}^{-1} \mathrm{yr}^{-1}$ in S1T1, S1T2, and S2T1, respectively.

\section{Discussion}

For the regression models developed for operational phases, $R^{2}$ were $0.57,0.66$, and 0.33 for felling and processing, forwarding, and loading, respectively (Table 7). Similar $R^{2}$ and significant predicator variables were observed by Hiesl and Benjamin (2015) and Proto et al. (2018). Butt-end diameter, distance traveled, and logs per cycle were found to be the significant variables for predicting DFC time (Nurminen et al. 2006; Ioan Apăfăian et al. 2017; Proto et al. 2018), thereby establishing a direct relation between the cost of the operation, average piece volume, and distance traveled by harvester and forwarder.

\section{Operational phases}

Processing time was the major contributor to the DFC time of the harvester (Nurminen et al. 2006; Ioan Apăfăian et al. 2017; Pajkoš et al. 2018). The higher processing time for S1T2 might be due to larger trees and higher percentage of hardwood extracted (48\%), which was only $13 \%$ in S1T1. Due to the presence of large branches and the forked nature of hardwoods, the operator spent more time processing hardwoods $(33.37 \pm 4.26 \mathrm{sec})$ than cedar or other softwoods $(15.20 \pm 0.82 \mathrm{sec})$ (Kizha and Han 2016). Further assortment of DFC supports this interpretation (Table 8).

The difference in felling and processing costs between the treatments could partially be due to the difference in average stem size between the treatments and equipment used (LeDoux and Huyler 2001; Puttock et al. 2005). There was a significant difference in dbh between the treatments in S1, however, S1T1 and S2T1 had trees with similar dbh. Even with a higher DFC time, the increased machine productivity when handling larger and higher numbers of logs per DFC subsequently decreased the cost of this operational phase in S1T2 (Nurminen et al. 2006; Baek 2018; Pajkoš et al. 2018). These arguments are validated by the regression models, in which butt-end diameter $(p<0.01)$ and number of $\operatorname{logs}(p<0.05)$ have a significant effect on DFC time (Table 7) (George et al. 2019).

The study could not directly attribute the increased cost of felling in S1T1 to the fragile forest floor. However, in S1T1, the average distance traveled was $1.42 \pm 0.09 \mathrm{~m}$ in an average time of $9.77 \pm 0.49 \mathrm{sec}\left(0.14 \mathrm{~m} \mathrm{sec}^{-1}\right)$ between successive cuts. While

Table 7. Regression models selected based on the lowest AIC values for predicting the delay-free cycle (DFC) time for the operational phases $(p<0.05)$. Data from S1T1, S1T2, and S2T1 were combined.

\begin{tabular}{|c|c|c|}
\hline Machine & $R^{2}$ & Standardized models predicting DFC time \\
\hline $\begin{array}{l}\text { Felling and } \\
\text { Processing } \\
\text { (Harvester) }\end{array}$ & 0.57 & $\begin{array}{l}\log \mathrm{DFC}=0.91^{* *}+0.03 \text { (number of logs per } \\
\text { cycle) })^{*}+0.11 \text { (hardwood) }^{* *}+0.11 \text { (softwood) } \\
*^{* *}-0.12(\mathrm{~S} 1 \mathrm{~T} 2)^{* *}+0.06(\mathrm{~S} 2 \mathrm{~T} 1)^{*}+0.05 \\
(\text { distance to deck) }+0.02 \text { (distance between } \\
\text { trees) })^{* *}+0.11 \text { (butt-end diameter) }\end{array}$ \\
\hline $\begin{array}{l}\text { Extraction } \\
\quad \text { (Forwarder) }\end{array}$ & 0.66 & $\begin{array}{l}\text { DFC }=3203.44^{* *}-14.19 \text { (in-woods travel } \\
\text { distance) }-568.00 \text { (number of logs per loading } \\
\text { cycle) }-171.94 \text { (number of logs per unloading } \\
\text { cycle) })^{*}+32.59 \text { (number of logs per extraction } \\
\text { cycle) }{ }^{* *}-953.25(\mathrm{~S} 1 \mathrm{~T} 2)^{* *}-789.36(\mathrm{~S} 2 \mathrm{~T} 1)^{* *}\end{array}$ \\
\hline $\begin{array}{l}\text { Loading (Self- } \\
\text { loading truck) }\end{array}$ & 0.33 & $\begin{array}{l}\log \text { DFC }=1.24^{* *}+0.03 \text { (number of logs per } \\
\text { cycle) })^{* *}+0.09(\text { six meter length log)** }+0.17 \\
\left.(\text { hardwood pulp) })^{* *}+0.11 \text { (pine sawlog) }\right)^{* *}\end{array}$ \\
\hline
\end{tabular}

Table 8. Cost (US\$ $\mathrm{m}^{-3}$ ) and productivity $\left(\mathrm{m}^{3} \mathrm{PMH}^{-1}\right.$, Productive Machine Hour) of felling and processing different assortments harvested from the treatments (George et al. 2019).

\begin{tabular}{lccc}
\hline Assortments & $\begin{array}{c}\text { Delay free cycle time } \\
(\mathrm{sec})\end{array}$ & Cost & Productivity \\
\hline Cedar & $27.23 \pm 0.87$ & 6.35 & 32.45 \\
Hardwood & $56.35 \pm 6.75$ & 6.09 & 33.83 \\
Softwood & $40.06 \pm 3.78$ & 5.66 & 36.40 \\
\hline
\end{tabular}


in S1T2 the machine traveled an average distance of $2.68 \pm 0.50$ $\mathrm{m}$ in an average time of $8.41 \pm 0.92 \mathrm{sec}\left(0.31 \mathrm{~m} \mathrm{sec}^{-1}\right)$, i.e., a greater distance in a shorter time $(p<0.01)$. This might be due to the microtopography of the terrain or limited ground stability as lowland cedar stands are characterized by numerous pits and mounds resulting from tree roots and buried deadwood (Chimner and Hart 1996; Slaughter and Skean 2003; Wesely et al. 2018). The presence of understory vegetation and regeneration might have also contributed to the increased travel time. Finally, stand density being two times greater in S1T1 than S1T2 (Table 1) may have impeded visibility and maneuverability in the former, thereby increasing travel time. Additional investigation is required to substantiate this observation. Ultimately, this harvest would not have been possible during summer due to fragile ground condition. In S2T1, rate of travel was $0.34 \mathrm{~m} \mathrm{sec}^{-1}$ (i.e., $1.56 \pm 0.48 \mathrm{~m}$ in $4.24 \pm 0.87 \mathrm{sec}$ ). This suggests an average rate of travel faster than that observed in S1T1; different operators in S1 and S2 may have influenced this outcome.

Productivity of the forwarders was in accordance with studies by Ioan Apăfăian et al. (2017), Proto et al. (2018), and Pajkoš et al. (2018) (Tables 4 and 5). Significant difference was observed between S1T1 and S1T2 $(p=0.03)$, and S1T2 and S2T1 $(p<0.01)$ for number of logs loaded per cycle. Ioan Apăfăian et al. (2017) and Nurminen et al. (2006) made similar observations and attributed the change in loading time to differences in stand characteristics. At the landing, unloading time was higher for S1T1 and S2T1 compared to S1T2, probably due to higher number and smaller size of logs within the load resulting in tangling of the logs during unloading (Table 5).

The loading phase was the most productive for both study sites (Table 4) (Kizha et al. 2020). The productivity of a self-loading truck has previously been found to be lower than a loader $\left(110 \mathrm{~m}^{3} \mathrm{PMH}^{-1}\right)$. But self-loading trucks are preferred when there is a constraint of landing space and for smaller-sized logs (Kizha and Han 2016; Soman et al. 2019).

\section{Effects of fluctuating labor and fuel costs}

Local sensitivity analysis was carried out to understand the fluctuation in cost of harvesting due to varying fuel price and labor cost, keeping all other factors constant. Even though the increase in the operational prices ranged between $7 \%$ and $9 \%$ due to a $50 \%$ increment in labor cost, such an increase would have a considerable impact in attracting a new work force to the trade. The shortage of machine operators is one of the major challenges faced by the industry (Koirala et al. 2017). Experienced operators also have an instrumental role on general timber harvesting (Kizha et al. 2020). These results can help in evaluating the optimal wage that could attract and retain skilled labor while being economically feasible for timber harvesting contractors. Even though the effects of variation in fuel price was only $5-6 \%$ variation in the in-woods operational cost, this would have a profound impact on the secondary transportation cost, which was not considered in this analysis (Kizha. et al. 2015; Paulson et al. 2019).

\section{Cost allocation based on DFC time for felling and processing}

Cost allocation showed that cost of felling and processing cedar was higher than other softwoods and hardwoods (Table 8; George et al. 2019), which can be due to the smaller size of cedar in the present study. The smaller size of the cedar trees may be the result of the lowland site conditions (muck soil); Parker et al. (1983) showed that trees growing in peat and bogs were slow-growing, stunted and smaller in size in comparison to those growing on well-drained soil. The percentage of wood recovery was also lower for cedar (2.2\% lost) when compared to other species $(0.97 \%$ lost $)$ harvested from the treatments (obtained from measurement certificates, generated by the harvester's measuring device). This might be attributed to the occurrence of heart rot disease, typical to cedar in these sites (Johnston 1990; Hofmeyer et al. 2009; Kenefic et al. 2019), leading to a greater number of cuts and fewer logs per DFC.

\section{Stand projection}

The stands were projected using FVS to determine the time required to regrow harvested merchantable volume. The relative differences in growth rate may to some extent be a factor of stocking, as stocking of S1T1 was somewhat higher than S1T2 and S2T1 after the harvest. However, growth rates for cedar stands of similar age (about 100 years old) on comparable sites ( site index at 50 years $=12 \mathrm{~m}$ ) can be inferred from yield tables (Boulfroy et al. 2012) and approximate $2.0 \mathrm{~m}^{3} \mathrm{ha}^{-1} \mathrm{yr}^{-1}$ across a range of stand densities. While it is reasonable to assume that growth rates in silviculturally managed stands will exceed those of cedar forests more generally, confirmation of projected growth in the present study through future remeasurement is warranted.

For the cedar stand, results obtained from FVS are comparable to the average annual mortality rate of $<0.2 \%$ observed regionally for cedar on average sites (Boulfroy et al. 2012). Whether the predicted reduction in tree numbers is accurate in these partially harvested stands is unknown until future remeasurements are made. While reductions in canopy closure should increase available light and thus improve growth and vigor of residual trees (Ruel et al. 2014), partial harvesting may increase windthrow of this shallow-rooted species in lowdensity areas or gap edges on lowland sites (Boulfroy et al. 2012). Factors such as these are not explicitly incorporated into the distance-independent FVS model and warrant future assessment. Nevertheless, if model outputs are accepted as reasonable, predicted time to regrow the harvested volume (20-22 years) for both treatment areas is comparable to a 20-year cutting cycle, which has been suggested for selection systems on poor sites (Frank and Bjorkbom 1973) and small-gap irregular shelterwood 
systems (Saunders et al. 2014) in the Acadian region. Remeasurements of the harvested stands will inform the accuracy of the model results.

\section{Conclusion}

This study examined the economic viability of timber harvesting operations on fragile soil and compared it with an operation conducted on sturdy soil. The fragile soils were replicated in another stand. The harvesting cost was higher for the cedar stands compared to the stand on sturdy soil accounting for an additional 54\% increment and can be attributed to smaller piece size as well as higher in-woods movement and loading times. Overall, the extraction cost accounted for $48 \%$ of the total inwoods operational costs. The extraction cost dropped by $34-41 \%$ when forwarding distance was changed. There was no considerable difference in the cost of operations between the fragile soil stand replicates ( $\$ 16.64$ and $13.17 \mathrm{~m}^{-3}$ ). Local sensitivity analysis revealed the variations in the cost of harvesting due to fuel price and operator wage.

Evidence from this study suggests that treatments as applied are operationally feasible. If model projections are accurate, outcomes are consistent with regional silvicultural guidance regarding future reentry in softwood-dominated stands. Projections of residual stand volume using FVS suggest the harvested areas will be operable again for the same volume at a cutting cycle length of about 20 years, though effects of spatially variable harvesting on residual stand growth and mortality are not well understood. This lack of information is not surprising, as cedar is one of the least-studied commercially valuable tree species in its range (Hofmeyer et al. 2007). Nevertheless, long-term sustainability will depend upon constraining future harvests to periodic growth, which - depending on cutting cycle - may or may not provide sufficient volume for an operable harvest. A quantitative understanding of stand and operational factors, including post-harvest growth and mortality, can help in efficient planning of economically feasible and sustainable harvest operations on similar lowland sites.

\section{Limitations of the study}

This study was conducted in collaboration with managers within the constraints of commercial forestland management, using stands selected for a larger study of silvicultural treatments. As such, there were some differences between stands in terms of soils and tree species composition, and between S1 and S2 in machinery and operators. Even though the treatment in the cedar stands was replicated at two sites, caution should be taken when applying findings more broadly until results are confirmed at other locations. Nevertheless, the field-collected data analyzed in the present study provide useful insights into timber harvesting and operational costs on commonly harvested but rarely studied stand and site types in the region, with relevance to similar sites and species elsewhere.

\section{Acknowledgements}

We would like to express our gratitude to Libin T. Louis, David Holmberg, Lauren Keefe, and Aaron Malone (University of Maine) for assisting in data collection. Liam Kenefic (University of Maine) helped with extraction of depth-to-water data. Our appreciation goes to Keith Kanoti, Robin Avery (University Forest, University of Maine System), Andrew Richley (US Forest Service), Kyle Burdick (Baskahegan Company), and Scott Barnes (Prentiss \& Carlisle Forest Resource Management and Timberland Service) for their involvement in the operational aspect of the study.

\section{Disclosure statement}

The authors declare that they have no known competing financial interests or personal relationships that could have appeared to influence the work reported in this paper.

\section{Funding}

This project was supported by the United States Department of Agriculture, National Institute of Food and Agriculture (McIntireStennis project number ME041909 through the Maine Agricultural and Forest Experiment Station); Cooperative Forestry Research Unit (CFRU); United States Forest Service, Northern Research Station and Northeastern States Research Cooperative.

\section{ORCID}

Anil Raj Kizha (D) http://orcid.org/0000-0002-5274-2255

\section{References}

Addison SL, Smaill SJ, Garrett LG, Wakelin SA. 2019. Effects of forest harvest and fertiliser amendment on soil biodiversity and function can persist for decades. Soil Biol Biochem. 135:194-205. doi:10.1016/j. soilbio.2019.05.006.

Ainslie WB. 2002. Forested Wetlands [Internet]. Asheville (NC): U.S. Department of Agriculture, Forest Service, Southern Research Station. [accessed 2019 Jul 12]. https://www.srs.fs.usda.gov/sustain/report/pdf/ chapter_20e.pdf .

Baek K. 2018. Productivity and cost of cut-to-length commercial thinning operation in a northern California redwood forest [Master of science in resources: forestry, watershed, \& wildland sciences] [Internet]. [place unknown]: Humboldt State University. [accessed 2019 Sep 18]. https:// digitalcommons.humboldt.edu/cgi/viewcontent.cgi? article=1135\&con text=etd .

Belair EP, Ducey MJ. 2018. Patterns in forest harvesting in New England and New York: using FIA data to evaluate silvicultural outcomes. J For. 116(3):273-282. doi:10.1093/jofore/fvx019.

Berry A, Bick S, Frederick P, Steele A, Mclarty M, Hollinger D. 2019. Warmer, wetter logging. The Northern Logger. p. 20-24.

Botti W. 1991. Condition of the Northern White-cedar resource. In: Lantagne DO, editor. Northern White-cedar in michigan. East Lansing: Michigan Agricultural Experiment Station, Michigan State University; p. 44-46.

Boulfroy E, Forget E, Hofmeyer PV, Kenefic LS, Larouche C, Lessard G, Lussier J-M, Pinto F, Ruel J-C, Aaron W. 2012. Silvicultural guide for northern white-cedar (eastern white cedar) [Internet]. Newtown Square (PA): U.S. Department of Agriculture, Forest Service, Northern Research Station. [accessed 2019 Jul 9]. doi:10.2737/NRS-GTR-98.

Canavan SJ, Ramm CW. 2000. Accuracy and precision of 10 year predictions for forest vegetation simulator: lake states. North J Appl For. 17 (2):62-70. doi:10.1093/njaf/17.2.62 
Chimner RA, Hart JB. 1996. Hydrology and microtopography effects on northern white-cedar regeneration in Michigan's Upper Peninsula. Can J for Res. 26(3):389-393. doi:10.1139/x26-043.

Crookston NL, Dixon GE. 2005. The forest vegetation simulator: a review of its structure, content, and applications. Comput Electron Agric. 49 (1):60-80. doi:10.1016/j.compag.2005.02.003.

Cudzik A, Brennensthul M, Białczyk W, Czarnecki J. 2017. Damage to soil and residual trees caused by different logging systems applied to late thinning. Croatian J For Eng. 38(1):83-95.

Dixon GE, Keyser CE. 2008. Northeast (NE) variant overview - Forest vegetation simulator [Internet]. Fort Collins (CO): U. S. Department of Agriculture, Forest Service, Forest Management Service Center. [accessed 2019 Jul 12]. https://www.fs.fed.us/fmsc/ftp/fvs/docs/over views/FVSne_Overview.pdf.

Frank RM, Bjorkbom JC. 1973. A silvicultural guide for spruce-fir in the Northeast [Internet]. Upper Darby (PA): U.S. Department of Agriculture, Forest Service, Northeastern Forest Experiment Station. [accessed 2020 Dec 14]. doi:10.2737/NE-GTR-6.

Frohn J. 2017. Looking for northern white cedar. University of New Hampshire Cooperative Extension [Internet]. [accessed 2019 Sep 9]. https://extension.unh.edu/blog/looking-northern-white-cedar .

George AK, Kizha AR, Kenefic L. 2019. Economic feasibility of timber harvesting in waterlogged cedar stands. Exceeding the vision: forest mechanization of the future. Proceedings of the 2nd International Symposium of Forestry Mechanization; Oct. 6-9; Sopron (Hungary); e-book p. 651. p. 379-393. http://formec2019.com/down/ FORMEC2019_PROCEEDINGS.pdf.

Han S-K, Han H-S, Page-Dumroese DS, Johnson LR. 2009. Soil compaction associated with cut-to-length and whole-tree harvesting of a coniferous forest. Can J For Res. 39(5):976-989. doi:10.1139/X09-027.

Heitzman E, Pregitzer KS, Miller RO. 1997. Origin and early development of northern white-cedar stands in northern Michigan. Can J For Res. 27 (12):1953-1961. doi:10.1139/x97-157.

Hiesl P, Benjamin GJ. 2015. Estimating processing time of harvesters in thinning operations in Maine. For Prod J. 65(3):180-186. doi:10.13073/ FPJ-D-14-00065.

Hofmeyer PV, Kenefic LS, Seymour RS. 2007. Northern White-cedar (Thuja occidentalis L.) an annotated bibliography [Internet]. Orono (ME): University of Maine, Cooperative Forestry Research Unit. [accessed 2019 Aug 11]. https://www.nrs.fs.fed.us/pubs/jrnl/2007/nrs_ 2007_hofmeyer_001.pdf.

Hofmeyer PV, Seymour RS, Kenefic LS. 2009. Influence of soil site class on growth and decay of Northern White-Cedar and two associates in maine. North J Appl For. 26(2):68-75. doi:10.1093/njaf/26.2.68.

Huff ES, McWilliams WH. 2016. Forests of Maine, 2015. Newtown Square (PA): U.S. Department of Agriculture, Forest Service, Northern Research Station.

Ioan Apăfăian A, Proto AR, Borz SA. 2017. Performance of a mid-sized harvester-forwarder system in integrated harvesting of sawmill, pulpwood and firewood. Ann Fort Res [Internet]. [accessed 2020 Jan 31]. doi:10.15287/afr.2017.909.

Jiang S. 2016. Forest harvesting impacts on forested wetland ecosystem functions in North America [Internet]. [accessed 2019 Jul 11]. doi:10.14288/1.0314337

Johnston WF. 1990. Thuja occidentalis L. - northern white-cedar. In: Silvics of North America. Vol. 1. Conifers. Edited by RM Burns and BH Honkala.[place unknown]: U.S. Department of Agriculture. 654pp. 1189-1209.

Keenan RJ. 2015. Climate change impacts and adaptation in forest management: a review. Ann For Sci. 72(2):145-167. doi:10.1007/s13595014-0446-5.

Kenefic L. 2013. New management strategies for Northern White-cedar [Internet]. [place unknown]: US Forest Service Northern Research Station. [accessed 2019 Aug 26]. https://www.nrs.fs.fed.us/news/ review/review-vol21rv2.pdf.

Kenefic L, Fraver S, Wason J, Kizha AR. 2019. Lowland white-cedar ecology and operations, and white-cedar old growth [Internet]. Orono (ME): Center for Research on Sustainable Forests, University of Maine. [accessed 2019 Jul 21]. https://nefismembers.org/documents/ lowland-white-cedar-ecology-and-operations-and-white-cedar-oldgrowth/.

Kenefic L, Kizha AR, Fraver S, Greig H, Roth A, Wason J, Kanoti K. 2018. Silviculture and operations in northern white-cedar lowlands: a pilot study [Internet]. Orono (ME): Cooperative Forestry Research Unit. [accessed 2019 Jul 8]. https:/umaine.edu/cfru/wp-content/uploads/ sites/224/2019/01/2018-CFRU-Annual-Report-20190119-Final.pdf .

Kizha AR, Han H-S. 2016. Processing and sorting forest residues: cost, productivity and managerial impacts. Biomass Bioenergy. 93:97-106. doi:10.1016/j.biombioe.2016.06.021.

Kizha AR, Han H-S, Anderson N, Koirala AT, Louis L. 2020. Comparing hot and cold loading in an integrated biomass recovery operation. Forests. 11(4):385. doi:10.3390/f11040385.

Kizha. AR, Han H-S, Montgomery T, Hohl A. 2015. Biomass power plant feedstock procurement: modeling transportation cost zones and the potential for competition. Calif Agric. 69(3):184-190. doi:10.3733/ca. v069n03p184.

Kizha AR, Nahor E, Coogen N, Louis LT, George AK. 2021. Residual stand damage under different harvesting methods and mitigation strategies. Sustainability. 13(14):7641. doi:10.3390/su13147641.

Koirala A, Kizha AR, Roth BE. 2017. Perceiving major problems in forest products transportation by trucks and trailers: a cross-sectional survey. Eur J For Eng. 3:23-34.

LeDoux CB, Huyler NK. 2001. Comparison of two cut-to-length harvesting systems operating in eastern hardwoods. Int J For Eng. 12(1):53-59.

Louis LT, Kizha AR. 2019. Comparing the cost of harvesting sawlogs and small-diameter trees from different silvicultural prescriptions utilizing two harvesting methods. Exceeding the Vision: Forest Mechanization of the Future Proceedings of the 2nd International Symposium of Forestry Mechanization; Oct. 6-9; Sopron, Hungary; e-book p. 651. p. 613-622. http://formec2019.com/down/FORMEC2019_ PROCEEDINGS.pdf.

Louis LT, Kizha AR. 2021. Wood biomass recovery cost under different harvesting methods and market conditions. Int J For Eng. 32 (2):164-173. doi:10.1080/14942119.2021.1874206.

Maine Forest Service. 2021. 2019 silvicultural activities report. Department of Agriculture, Conservation and Forestry, Maine Forest Service, Forest Policy and Management Division. https://www.maine. gov/dacf/mfs/publications/annual_reports.html .

Miyata ES. 1980. Determining fixed and operating costs of logging equipment [Internet]. Minnesota: North Central Forest Experiment Station. [accessed 2019 Mar 9]. https://www.nrs.fs.fed.us/pubs/gtr/gtr_nc055. pdf.

Murphy PNC, Ogilvie J, Meng FR, White B, Bhatti JS, Arp PA. 2011. Modelling and mapping topographic variations in forest soils at high resolution: a case study. Ecol Modell. 222(14):2314-2332. doi:10.1016/j. ecolmodel.2011.01.003.

Nurminen T, Korpunen H, Uusitalo J. 2006. Time consumption analysis of the mechanized cut-to-length harvesting system. Silva Fenn [Internet]. 40(2). [accessed 2019 May 28]. doi:10.14214/sf.346.

Pajkoš M, Klvač R, Neruda J, Kumar Mishra P. 2018. Comparative time study of conventional cut-to-length and an integrated harvesting method-a case study. Forests. 9(4):194. doi:10.3390/f9040194.

Parker WH, Knowles P, Bennety A, Gray A, Krikl T. 1983. Habitatdependent morphological and chemical variation in Picea mariana from northwestern Ontario. Can J Bot. 61(6):1573-1579. doi:10.1139/ b83-170.

Paulson J, Kizha A, Han H-S. 2019. Integrating biomass conversion technologies with recovery operations in-woods: modeling supply chain. Logistics. 3(3):16. doi:10.3390/logistics3030016.

PIN (Penobscot Indian Nation). Wetland information. Penobscot Indian Nation [Internet]. [accessed 2020 Apr 24]. https://www.penobscotna tion.org/departments/natural-resources/wildlife-and-wetlands/wet land-information .

Proto AR, Macrì G, Visser R, Harrill H, Russo D, Zimbalatti G. 2018. Factors affecting forwarder productivity. Eur J For Res. 137(2):143-151. doi:10.1007/s10342-017-1088-6. 
Puttock D, Spinelli R, Hartsough BR. 2005. Operational trials of cut-tolength harvesting of poplar in a mixed wood stand. Int J For Eng. 16 (1):39-49. doi:10.1080/14942119.2005.10702506.

Rossman R, Corcoran J, Sleasak R. 2016. Timber harvesting and forest management guideline implementation on public and private forest land in various watersheds in Minnesota monitoring for implementation 2014 \& 2015 [Internet]. St. Paul (Minnesota): Minnesota Department of Natural Resources, Division of Forestry. [accessed 2019 Jul 19]. https://www.leg.mn.gov/docs/2016/mandated/160277. pdf.

Ruel J-C, Lussier J-M, Morissette S, Ricodeau N. 2014. Growth response of Northern White-cedar (Thuja occidentalis) to natural disturbances and partial cuts in mixedwood stands of Quebec, Canada. Forests. 5 (6):1194-1211. doi:10.3390/f5061194.

Runkel J, Kunkel K, Champion S, Frankson R, Stewart B, DeGaetano AT. 2017. Maine state climate summary [Internet]. Maine: National Oceanic and Atmospheric Administration. [accessed 2019 Jul 21]. https://statesummaries.ncics.org/chapter/me/ .

Russell R, Blinn C, Gupta A. 2018. Harvesting timber: why do we harvest trees in the winter? University of Minnesota [Internet]. [accessed 2020 Sep 9]. http://www.myminnesotawoods.umn.edu/2018/01/why-do-weharvest-trees-in-the-winter/.

Saunders MR, Seymour RS, Wagner RG. 2014. The Acadian forest ecosystem research program: an example of natural disturbance-based silviculture in the northeast [Internet]. Newtown Square (PA): U.S. Department of Agriculture, Forest Service, Northern Research Station. [accessed 2019 Jul 11]. https://www.fs. fed.us/nrs/pubs/gtr/gtr-nrs-p-123papers/05SaundersSeymourWagnerp-123.pdf .

Slaughter BS, Skean JD. 2003. Comparison of cedar and tamarack stands in a relic conifer swamp at Pierce Cedar Creek Institute, Barry County, Michigan. The Michigan Botan. 42:111-126.
Soil Survey Staff. Natural resources conservation service. Web soil survey [Internet]. [accessed 2019 Jun 5]. https://www.nrcs.usda.gov/wps/por $\mathrm{tal} / \mathrm{nrcs} /$ detail/soils/survey/tools/?cid=nrcseprd1407030 .

Soman H, Kizha AR, Delgado BM, Kenefic LS, Kanoti K. 2020. Production economics: comparing hybrid tree-length with whole-tree harvesting methods. Forestry Int J For Res. 1-12. doi:10.1093/forestry/cpz065.

Soman H, Kizha AR, Roth BE. 2019. Impacts of silvicultural prescriptions and implementation of best management practices on timber harvesting costs. Int J For Eng. 30(1):14-25. doi:10.1080/14942119.2019.1562691.

Tiner RW. 2007. Maine wetlands and waters: results of the national wetlands inventory [Internet]. Hadley (MA): U.S. Fish and Wildlife Service, Northeast Region. [accessed 2019 Jul 11]. https://www.fws. gov/wetlands/Documents\%5CMaine-Wetlands-and-Waters-Results-of -the-National-Wetlands-Inventory.pdf .

UNB Forest Watershed Research Center. 2014. Cartographic depth-towater mapping using latest DEM coverage for CFRU priority areas.

Venables WN, Ripley BD. 2002. Modern applied statistics with S. 4th ed. New York: Springer.

Verme LJ, Johnston WF. 1986. Regeneration of Northern White cedar deeryards in upper michigan. J Wildl Manage. 50(2):307. doi:10.2307/3801918.

Waters I, Kembel SW, Gingras J-F, Shay JM. 2004. Short-term effects of cut-to-length versus full-tree harvesting on conifer regeneration in jack pine, mixedwood, and black spruce forests in Manitoba. Can J For Res. 34(9):1938-1945. doi:10.1139/x04-064.

Wesely N, Fraver S, Kenefic L, Weiskittel A, Ruel J-C, Thompson M, White A. 2018. Structural attributes of old-growth and partially harvested Northern White-cedar stands in Northeastern North America. Forests. 9(7):376. doi:10.3390/f9070376.

Woodall C, Munoz DB, Kenefic L, Kern CB. 2019. Status and trends of Northern White-cedar in the U.S. Orono (ME): Center for Research on Sustainable Forests, University of Maine. 